1970. This is a considerable flaw. There has been a publishing explosion in this decade, and students and scholars must use a great deal of the excellent material published since 1969-70. It is of course true that this material is relatively easy to find. But students and academics are notoriously weak as bibliographers, and can use all the assistance that is available.

Perhaps the most serious criticism of the book concerns its price, a matter outside the compiler's control. At $\$ 75.00$ this book, which should be in the hands of every serious student of Canadian politics, will be owned only by libraries and book reviewers. Bibliographies, of course, are expensive to produce. In this case no effort seems to have been made to limit costs. The book is double columned and set in regular type. The result is a very fine example of the bookmaker's art, but type-set bibliographies in Canada have for the most part been replaced by books printed photographically from typescript. This is a much cheaper technique.

In summary, it should be said that Grace Heggie has done a great service to Canadian scholarship by compiling a first-rate bibliography. The book is beautifully organized and exceptionally well produced. In a new edition, however, minor errors should be corrected and the book should include more recent material. And the price should be reduced so that the volume will receive the wide use that it deserves.

Donald Swainson

(Dr. Swainson teaches in the History Department of Queen's University, Kingston, and is the author of many books and articles on Canadian history and politics.)

Checklist of Kingston Imprints to 1867, edited by A.R. Hazelgrove. Kingston: Douglas Library, Queen's University, 1978. (Douglas Library Occasional Papers no.5.) xix, 118p., illus., card covers, $\$ 5.00$ (from Special Collections, Douglas Library, cash with order)

This late comer in the Tercentenary publications from Kingston is a most useful list of material published or printed in Kingston before Confederation. It includes some items which were merely sold in Kingston where the name of the bookseller appears on the material.

H. Pearson Gundy in the Foreword gives a brief, informative capsule history of printing and publishing in Kingston. The compilers and editor have supplied descriptive notes and an index which give just the right amount of information and make subjects easy to find. The list is divided into monographs, periodicals and serials with a further division chronologically. Many of the monographs were published by the Queen's Printers, Desbarats and Derbyshire, when Kingston was the capital. Under periodicals is a rather remarkable list of early newspapers and, having used those papers, I think that notations "incomplete" or "partial" may be overstating the case.

I have only one question about this checklist. The repetition of the notation "Not seen" began to annoy me. Was the editor questioning whether these things existed or did he feel he had to see them to guarantee their existence? Surely it is sufficient that his Introduction states he has seen nothing in libraries outside of Kingston. Then he could have made some special notation about those in Kingston which, while listed in other bibliograpies, could not be located.

We can hope this excellent Checklist will encourage other compilers to cover other Canadian publishing centres in like manner.

Margaret Angus

(Dr. Angus, historian and author, is a Director of the Ontario Historical Studies Series and an inveterate user of libraries.)

Cities of Canada. Volume I: Theoretical, Historical and Planning Perspectives; Volume II: Profiles of Fifteen Metropolitan Centres. [By] George A. Nader, Trent University. Toronto: Macmillan of Canada/Maclean Hunter Press, 1975-6. 404 \& 460 p., illus., bibliogs., cloth, $\$ 17.50$ \& $\$ 18.95$ ISBN 0-7705-1029-9 \& 0-7705-1239-9

Volume I concerns urban structure (the city centre), historical development, and prospects, in Canada. In discussing the future, Professor Nader analyses the planning, finance, and public policy involved, as well as the institutional-governmental arena where the solutions will have to be thrashed out.

Volume II presents detailed histories and descriptions of 15 Canadian cities from St. John's, Nfld. to Victoria, B.C. Economics, land use, downtown problems, municipal government, and planning, are all considered for each city. 
Both volumes are rich in plans, diagrams, tables, and illustrations, and are replete with indexes. Each contains a good beginning bibliography of the book's subject, of 18 and 19 pages, unannotated, and listing books and articles; that in volume I itself includes bibliographies, and volume II includes publications of both the 19th and 20th centuries.

\section{Review Editor}

Dictionary of Canadian Biography, Volume IX, 1861 to 1870 . Editors: F.G. Halpenny and J. Hamelin. Toronto: University of Toronto Press, 1976. 967 p., cloth, $\$ 20.00$ ISBN 0-8020-3319-9

It is now 12 years ago since the first volume of the Dictionary of Canadian Biography/ Dictionnaire biographique du Canada was published. Since 1966 four more volumes have appeared, while another six volumes are in preparation. In 1972 the $D C B$ published the first volume (X) for the nineteenth century, convering the decade of 1871 to 1880. Volume IX deals with persons of Canadian interest who died during the Confederation decade of 1861-70. Hopefully, the next volume to be published will be number XI (1880-90). After all, the men and women who died between 1860 and 1890 represent together all the major themes of Canada's checkered nineteen th century.

Volume IX consists of 524 different biographies, written by more than 300 contributors, many of whom are professional historians. The articles range from brief summaries to full-scale biographical essays of up to twelve thousand words. There is perhaps some irony in the fact that the two longest essays deal with the two great antagonists of the second quarter of the nineteenth century: W.L. Mackenzie, the rebel of 1837 , and J. Strachan, the godfather of the Family compact. The biography of each runs fourteen pages.

The fact that the nineteenth century was in a unique way the age of politics and politicians is reflected in a preponderant number of articles dealing with governors, politicians and public men. In addition to the biographies of Mackenzie and Strachan, there are articles on D'Arcy McGee, Allan MacNab, J.B. Robinson, W.H. Merritt, L.H. La Fontaine and J.B.E. Dorion - almost household names to those familiar with Canadian History. At the same time, there is a wealth of information about significant Canadians in other areas: religion, education, commerce, fur trade, exploration, cultural life. Laura Secord, the heroine of the War of 1812, is included as well as Theophile Hamel, the Quebec portrait painter, who was commissioned in 1853 to paint the portraits of all the speakers of the assemblies and legislative councils since 1791 .

Refreshingly, there is little evidence of a "centralist" bias in the selection of biographies. The editors have made a successful attempt to include significant Canadians who died between 1861 and 1870 from Newfoundland to British Columbia.

As is the case with the four volumes published previously, Volume IX is comprehensive, scholarly and, yet, eminently readable. The biographies have been written according to the directives to the contributors, namely to write an orderly account of both personality and achievements "against the background of the period in which the person lived and the events in which he or she participated."

Those who have a special research interest will benefit from the bibliographical information in the list of primary and secondary sources which follows every article. One minor improvement which could have been made is the addition of a separate index of all the biographies in this book. As it is, they now have to be culled from a lengthy cross-reference index which runs 52 pages in length.

The volumes of the $D C B$ are of absorbing interest to the professional historian and the university student. They should also have a wide appeal to all those who are fascinated by Canada's past. It is perhaps too much to expect that this volume will be read "from cover to cover", as the jacket suggests, but it certainly is a thoroughly enjoyable book "to be dipped in to at leisure". As a scholarly reference text on Canada's nineteenth century, it is indispensable.

Anthony J. Looy

(Dr. Looy teaches Canadian history at Queen's University. His Ph.D. thesis dealt with Indian administration in Western Canada in the late nineteenth century.)

English-Canadian Literature to 1900: A Guide to Information Services. [By] R.G. Moyles. Detroit, Michigan: Gale Research Company, 1976. xii, 346p., hard, $\$ 18.00$ ISBN 0-8103-1222-0. 